\title{
Model Optimisasi Linier Integer untuk Masalah Pemilihan Media Periklanan dengan menggunakan Pendekatan Konsep Set Covering
}

\author{
Diah Chaerani, Erna, Stanley P. Dewanto \\ Jurusan Matematika FMIPA Universitas Padjadjaran \\ Jalan Raya Bandung Sumedang KM 21 Jatinangor 45323 Indonesia \\ e-mail: d.chaerani@unpad.ac.id
}

\begin{abstract}
ABSTRAK
Dalam paper ini disajikan kajian model optimisasi strategi pemilihan media periklanan dengan menggunakan pendekatan konsep set covering (SC). Pentingnya disain model masalah ini terletak pada konstruksi fungsi kendala sebagai masalah SC, dimana himpunan tipe audiens diasumsikan sebagai suatu himpunan yang terlingkupi oleh himpunan media yang tersedia. Ini berarti bahwa himpunan media beranggotakan sub himpunan dari himpunan tipe audiens. Tujuan utama dari masalah pemilihan media periklanan ini dapat dinyatakan sebagai masalah optimisasi untuk menentukan kombinasi terbesar dari setiap anggota dari himpunan media yang melingkupi (atau disebut sebagai suatu cover) atas himpunan audiens dengan biaya promosi periklanan yang minimum. Dapat ditunjukkan bahwa model optimisasi yang diperoleh merupakan masalah Integer Linier Programming (ILP), sehingga masalah ini harus diselesaikan dengan menggunakan metode/skema branch and bound dalam perhitungan numeriknya. Selanjutnya, untuk memperoleh suatu model optimisasi yang memperhatikan kondisi logis di dunia nyata, maka disajikan pula penambahan kondisi logis dengan konstruksi fungsi kendala menggunakan konsep conditional constraints. Contoh masalah yang disajikan dalam makalah ini merujuk pada [1].
\end{abstract}

Keywords: optimisasi, pemrograman linier integer, set covering, periklanan, skema branch and bound

\section{ABSTRACT}

In this paper the study of optimization model for an advertising media problem with set covering concept. The importance of this model is the construction on the model via SC, where the set of audience types is assumed as a set which is included in the set of the media itself. This means that the media set consists of subsets of audience types set. The main goal of the model is to determine the largest combination of each element of the media set which covered by audience sets with the minimum cost. It is shown that the problem can be modeled as an Integer Linear Programming (ILP) problem, this problem is solved by Branch and Bound Methods. Furthermore, to be more precise with the real world problem, we discuss how logical constraints is added in the construction model. The presented examples is refers to [1].

Keywords: Optimization, ILP, set covering, advertising media, branch and bound 


\section{Pendahuluan}

Periklanan adalah segala bentuk penyajian dan promosi ide, barang, atau jasa secara non-personal oleh suatu sponsor tertentu yang memerlukan pembayaran [2]. Iklan merupakan salah satu contoh untuk mengenalkan produk atau jasa yang ingin dipasarkan kepada pasar sasaran. Iklan sangat berperan penting dalam dunia pemasaran. Tujuan iklan sangat tergantung dari setiap perusahaan, baik untuk menginformasikan, membujuk, atau mengingatkan. Dalam periklanan diperlukan strategi dan penjadwalan yang tepat agar iklan yang dikeluarkan sesuai dengan harapan.

Penjadwalan media merupakan bagian yang penting dari penjadwalan periklanan. Penjadwalan media meliputi pemilihan media periklanan, banyaknya iklan yang akan dipasang disetiap media periklanan, dan pemilihan waktu yang tepat untuk melakukan periklanan. Gambar 1 merupakan bagan dari penjadwalan periklanan yang menggambarkan posisi pentingnya penjadwalan media dalam kerangka kampanye periklanan. Selain itu dapat dilihat bagaimana peran dan fungsi penting dari penjadwalan media sehingga sangat mempengaruhi pengaturan biaya dan strategi penjadwalan periklanan.

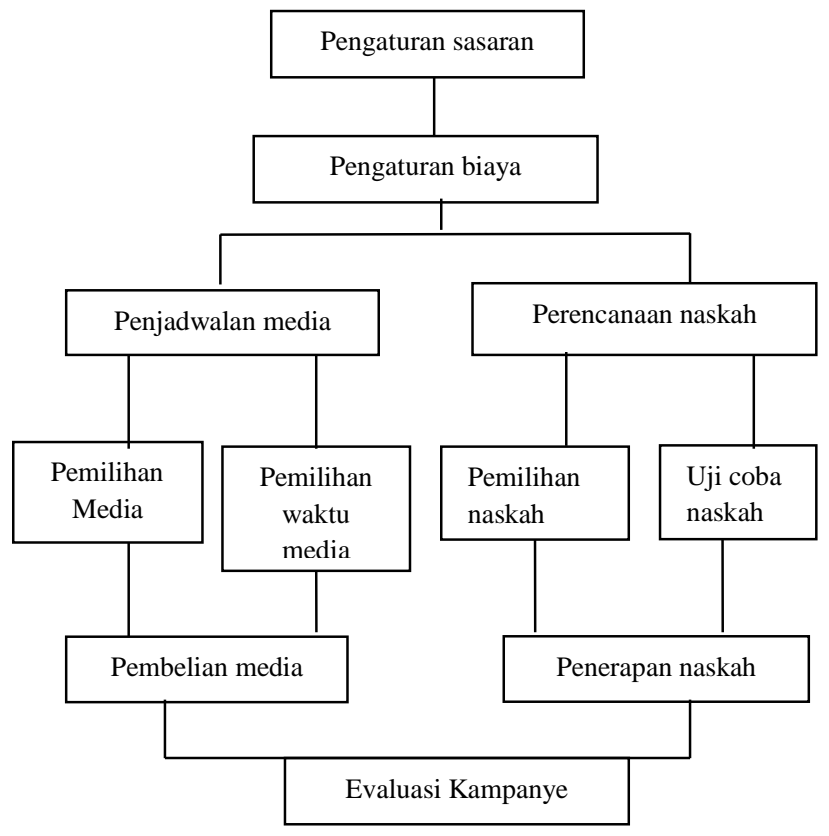

Gambar 1. Kerangka kampanye periklanan [2]

Pengambilan keputusan yang dilakukan pada kampanye periklanan melibatkan seluruh elemen yang ada pada Gambar 1. Pengaturan biaya yang melibatkan 
penjadwalan media dan perencanaan naskah menjadi bagian yang utama selain juga penentuan target/sasaran.

Menurut Calantone et al [2], pemrograman matematika pertama kali diterapkan dalam masalah penjadwalan media pada tahun 1961. Model pemilihan media yang menggunakan linear programming pertama kali diperkenalkan oleh Young dan Rubicam (1961) tujuannya adalah mengoptimalkan perhitungan biaya pemilihan media. Dalam perkembangannya model pemilihan media yang menggunakan metode optimisasi merupakan model integer programming yang variabel keputusannya bernilai integer.

Dalam masalah pemilihan media, dapat digambarkan bahwa tidak semua media dapat menjangkau semua target, sehingga diperlukan beberapa strategi yang dapat memuat semua jenis target yang telah ditentukan. Beberapa strategi yang dipilih adalah dengan menambahkan beberapa kondisi logis di lapangan. Untuk memperoleh alternatif strategi yang terbaik, masalah pemilihan media dapat diselesaikan dengan konsep pemodelan Set Covering. Dalam makalah ini disajikan pembahasan mengenai pendekatan set covering ini.

Pembahasan dimulai dengan dengan paparan singkat mengenai teori dan konsep Set Covering pada Subseksi 3. Paparan mengenai perumusan Masalah Pemilihan Media Periklanan disajikan pada Subseksi 3. Dalam subseksi ini, pembahasan diawali dengan perumusan masalah, karakterisasi pemodelan optimisasi kemudian dilanjutkan dengan penyajian model optimisasi pemilihan media periklanan yang diperoleh melalui pendekatan konsep Set Covering. Dalam hal ini dapat dilihat pada Subseksi 3.3, bahwa model yang diperoleh adalah Model Optimisasi Linier Integer. Subseksi 4 menyajikan contoh kasus dan hasil perhitungan simulasi menggunakan software aplikasi Mapple 10. Kesimpulan dan Saran disajikan pada Subseksi 5.

\section{Teori Pendukung}

Pada subseksi ini, dibahas teori pendukung yang digunakan dalam makalah ini, yaitu teori dan konsep Set Covering yang merujuk pada referensi [5] dan teori mengenai Conditional Constraints yang merujuk pada referensi [1].

\subsection{Konsep Set Covering [5]}

Definisi 3.1 Misalkan diberikan himpunan $S$ dan $U=\left\{U_{1}, U_{2}, U_{3}, \ldots, U_{n}\right\}$ $F=S_{1}, S_{2}, S_{3}, \ldots, S_{n}$ subset dari $S$ (dengan kata lain, $U_{j} \subseteq S, J \subseteq\{1, . ., n\}$

$\left.U_{j} \subseteq S_{j} j=1 \ldots n S_{j} \subseteq X_{j} j=1, \ldots, n\right)$. Masalah Set Covering adalah suatu masalah dengan tujuan untuk menentukan kardinalitas minimal dari $J \subseteq\{1, . ., n\}$ sedemikian sehingga berlaku 


$$
\bigcup_{j \in J} U_{j}=S
$$

Setiap $s_{i} \in S$, dinamakan titik-titik (points). Misalkan diberikan $\rceil \subseteq\left\{1_{\left.y_{m}, n\right\}}\right.$, suatu titik (point)

$$
\mathrm{U}_{j \in J} S_{j}=X
$$

dikatakan akan di-cover, jika titik(point) tersebut termasuk dalam

$$
\bigcup_{j \in J} U_{j}=\bigcup_{j \in J} U_{j} \text {. }
$$

Dalam Masalah Biaya Minimum Set Covering, setiap himpunan $U_{j}, 1 \leq j \leq n$ $U_{j} 1 \leq j \leq n S_{j} 1 \leq j \leq n$, memiliki biaya $c_{j}$ dimana masalah yang harus diselesaikan adalah menentukan menentukan kardinalitas minimal dari $J \subseteq\{1, . ., n\} I \subseteq\{1, \ldots, n\}$ dengan $\sum_{j=1}^{n} c_{j}$ minimum

\section{Definisi 3.2.}

Matriks Asu untuk masalah Set Covering. Misalkan $|S|$ adalah jumlah baris pada matriks $A_{S U}$, untuk setiap $s_{i} \in S x_{i} \in X$, dan n adalah jumlah kolom pada matriks AsU, untuk setiap himpunan $U_{j}$. Maka entri pada matriks AsU dapat didefinisikan sebagai berikut

$$
A_{S U}=\left\{\begin{array}{l}
1, \text { jika } s \in S \text { termuat dalam } U \\
\text { 0, lainnya. }
\end{array}\right.
$$

Selanjutnya, masalah Set Covering ini dapat diformulasikan sebagai masalah integer programming (IP). Hal ini dapat dilakukan dengan cara definisikan untuk setiap himpunan $U_{j} S_{j}$, variabel $\mathrm{x}_{j}$ bernilai 0 dan 1 . Jika variabe $x_{j}=1$, $s_{j}=1$ maka himpunan $U_{j} S_{j}$ merupakan solusi optimal. Misalkan $1^{m}$ menunjukkan vector dimensi $m$, yang masing-masing bernilai 1 ,maka model IP untuk masalah set covering dapat diformulasikan sebagai berikut.

$$
\min \left\{\sum_{j=1}^{n} x_{j}: A_{S U} x \geq 1^{m}, x_{j} \in\{0,1\}, j=\{1,2, . ., n\}\right\} .
$$

Selanjutnya, definisikan $c_{j}$ sebagai biaya yang harus dikeluarkan untuk setiap pemilihan himpunan $U_{j}$, Dengan demikian untuk meminimumkan biaya pada masalah set covering maka model optimisasi biaya pada masalah set covering dapat ditulis sebagai formulasi dibawah ini.

$$
\min \left\{\sum_{j=1}^{n} c_{j} x_{j}: A_{S U} x \geq 1^{m}, x_{j} \in\{0,1\}, j=\{1,2, . ., n\}\right\} .
$$




\subsection{Conditional Constraints [1]}

Dalam Integer programming (lihat [3],[4],[6]), ada beberapa cara yang digunakan untuk menyelesaikan masalah praktis. Masalah ini dikenal dengan trik integer programming. Salah satu cara yang digunakan dalam trik integer programming adalah dengan menambahkan kondisi logis. Kondisi logis dapat dinyatakan dalam kendala bersyarat atau dikenal dengan conditional constraint dan either-or constraint. Pandang masalah pemrograman linier berikut

$$
\begin{gathered}
\min \sum_{j=1}^{n} c_{j} x_{j}, \\
\text { s.t } \sum_{\mathrm{j}=1}^{\mathrm{n}} \mathrm{a}_{1 \mathrm{j}} x_{j} \leq b_{1}, \\
\sum_{\mathrm{j}=1}^{\mathrm{n}} \mathrm{a}_{2 \mathrm{j}} x_{j} \leq b_{2}, \\
x_{j} \geq 0 .
\end{gathered}
$$

dimana syarat dari either-or constraint adalah salah satu dari dua kendala yang ada harus dipilih. Maka jika variabel biner ditambahkan dan mempunyai batasan $M$ yang sangat besar, maka fungsi kendala (6) dan (7) menjadi

$$
\begin{gathered}
\sum_{\mathrm{j}=1}^{\mathrm{n}} \mathrm{a}_{1 \mathrm{j}} x_{j} \leq b_{1}+M y, \\
\sum_{\mathrm{j}=1}^{\mathrm{n}} \mathrm{a}_{2 \mathrm{j}} x_{j} \leq b_{2}+M(1-y),
\end{gathered}
$$

Jika $y=0$ maka batasan kedua menjadi berlebihan, dan batasan pertama tetap aktif. Demikian jika $y=1$ maka batasan kedua menjadi aktif, bukan batasan pertama. Dengan dimasukannya variabel biner $y$ karena itu membuat batasanbatasan ini menjadi bentuk dimana pemrograman integer linier dapat diterapkan.

Pada penambahan conditional constraint, akan melibatkan dua kendala, kedua kendala tersebut harus dipilih. Model dari kendala tersebut adalah sebagai berikut.

$$
\begin{array}{r}
\text { Jika (1) }\left\{\sum_{j=1}^{n} a_{1 j} x_{j} \leq b_{1}\right\} \text { memenuhi maka } \\
\text { (2) }\left\{\sum_{j=1}^{n} a_{2 j} x_{j} \leq b_{2}\right\} \text { harus memenuhi. }
\end{array}
$$

Misalkan A menyatakan bahwa pernyataan kondisi logis "kendala (1) berlaku" adalah benar, dan B menyatakan bahwa pernyataan kondisi logis "kendala (2) 
berlaku" adalah benar dan notasi - A dan - B mewakili pernyataan kondisi logis adalah salah. Kendala bersyarat tersebut dapat dinyatakan menjadi A menyiratkan B, hal ini dapat menyatakan bahwa (A dan - B) adalah salah sedangkan - (A dan - B) adalah benar. Dengan kata lain dapat dinyatakan bahwa (- A atau B) adalah benar. Dapat dilihat ilustrasi berikut:

$$
\begin{array}{r}
\text { Jika(1) }\left\{\sum_{j=1}^{n} a_{1 j} x_{j} \leq b_{1}\right\} \text { berlaku maka } \\
\text { (2) }\left\{\sum_{j=1}^{n} a_{2 j} x_{j} \leq b_{2}\right\} \text { harus berlaku. }
\end{array}
$$

Pernyataan di atas sama dengan

$$
\begin{aligned}
& \text { (1) }\left\{\sum_{j=1}^{n} a_{l j} x_{j} \leq b_{1}\right\} \text { berlaku atau } \\
& \text { (2) }\left\{\sum_{j=1}^{n} a_{2 j} x_{j} \leq b_{2}\right\} \text { harus berlaku. }
\end{aligned}
$$

Selanjutnya, pada Subseksi 3, disajikan pembahasan mengenai Masalah Pemilihan Media Periklanan.

\section{Masalah Pemilihan Media Periklanan}

Optimisasi digunakan dalam bidang kajian marketing untuk mengoptimalkan alokasi budget periklanan diantara beberapa jenis iklan yang ada. Masalah ini dikenal dengan sebagai Masalah Optimisasi Pemilihan Media Periklanan.

Fokus permasalahan yang dibahas dalam makalah ini adalah bagaimanakah cara memodelkan masalah pemilihan media periklanan ini ke dalam suatu model optimisasi dengan menggunakan pendekatan konsep Set Covering. Dengan demikian, merunut pada konsep pemodelan optimisasi secara umum, dalam hal ini perlu dilakukan suatu tahap penentuan dan pencarian strategi pemilihan media yang optimal sedemikian sehingga dapat meminimalkan biaya pemilihan media periklanan ini. Selanjutnya, pada subseksi berikut ini dibahas pengenai perumusan masalah secara lebih detail.

\subsection{Perumusan Masalah}

Misalkan sebuah perusahaan akan membuat suatu promosi untuk mengiklankan suatu produk baru. Beberapa tipe audien telah diidentifikasi sebagai target audien untuk produk baru tersebut. Selanjutnya, terdapat suatu kelompok media yang dapat dipilih untuk mencapai berbagai target audiens. Namun demikian tidak ada satupun media periklanan tersebut yang dapat 
mencapai seluruh tipe audien. Konsekuensinya, beberapa jenis media harus dipilih pada waktu bersamaan untuk dapat mencapai seluruh target audien. Dengan kondisi ini, maka perusahaan ingin melakukan suatu investigasi dalam pemilihan strategi periklanan. Tujuannya bukan untuk membelanjakan sejumlah budget yang telah ditetapkan, tetapi untuk meminimumkan biaya total pemilihan media untuk setiap pemilihan strategi. Selanjutnya pada Subseksi 3.2 disajikan disain model pemilihan media periklanan ini dengan menggunakan pendekatan konsep Set Covering.

\subsection{Formulasi Model}

Dengan menggunakan asumsi masalah seperti yang disebutkan pada Subseksi 3.1, formulasi model dapat dilakukan dengan mendefinisikan notasi indeks, parameter dan variable yang akan digunakan dalam pemodelan, baik untuk formulasi fungsi tujuan maupun fungsi kendala untuk masalah yang tengah dibahas.

Perhatikan, konsep Set Covering digunakan pada pendefinisian himpunan tipe audiens $S$ dan himpunan jenis media periklanan yang tersedia, $U$. Misalkan terdapat $m$ tipe audien dan $n$ jenis media, maka $S=\left\{s_{1}, s_{2}, . ., S_{m}\right\}$ dan $U=\left\{u_{1}, \mathrm{u}_{2}, . ., \mathrm{u}_{m}\right\}$ dimana setiap subset dari himpunan media $U_{j}$ merupakan subset dari himpunan tipe audien $S$ yaitu $U_{j} \subseteq S, j=1, . ., n$. Dalam hal ini, setiap tipe audien $s_{i}, i=1, . ., m$ merupakan titik atau point yang akan di-cover atau dijangkau oleh sembarang himpunan gabungan $U_{j}$. Selanjutnya, pendekatan konsep Set Covering juga memungkinkan untuk mendefinisikan suatu matrik insidensi $A_{S U}$ dimana untuk masalah ini, dapat didefinisikan sebagai berikut

$$
\left(A_{S U}\right)_{i j}=\left\{\begin{aligned}
1, & \text { jika tipe audien } s_{i} \in S, i=1,2, ., m \\
& \text { ter-cover dalam } U_{j}, j=1,2, . ., n \\
0, & \text { lainnya. }
\end{aligned}\right.
$$

Dengan menotasikan variable keputusan sebagai variable biner $x_{j}$ dapat didefinisikan bahwa

$$
\begin{aligned}
& x_{j}=\left\{\begin{array}{l}
1, \text { jika } U_{j} \text { merupakan bagian dari cover, } \\
0, \text { lainnya. }
\end{array}\right. \\
& y_{u}=\left\{\begin{array}{l}
1, \text { jika } u \in U \text { adalah bagian dari cover, } \\
0, \text { lainnya. }
\end{array}\right. \\
& a_{s u}=\left\{\begin{array}{l}
1, \text { jika } s \in S \text { termuat dalam } u \in U \\
0, \text { lainnya }
\end{array}\right.
\end{aligned}
$$


Fungsi tujuan didefinisikan sebagai fungsi minimasi dari fungsi biaya periklanan dimana variabel keputusan yang harus ditentukan adalah kardinalitas minimal dari ukuran himpunan $U_{j}$ yang merupakan cover dari himpunan $S$.

$$
\min \sum_{j=1}^{n} c_{j} x_{j}
$$

dimana $c_{i}$ adalah biaya periklanan untuk media $i$. Selanjutnya, karena tidak satupun media yang dapat menjangkau seluruh audien pada suatu waktu, maka hal ini mengakibatkan setiap tipe audien harus dapat dijangkau oleh media yang tersedia, paling sedikit satu kali. Maka fungsi kendala untuk masalah ini dapat diformulasikan sebagai berikut.

$$
\sum_{i=1}^{m}\left(A_{S U}\right)_{i j} x_{j} \geq 1, \forall j=1,2, . ., n
$$

Dengan demikian, model optimisasi pemilihan media periklanan dapat diformulasikan sebagai berikut:

$$
\min \left\{\sum_{j=1}^{n} c_{j} x_{j}: \sum_{i=1}^{m}\left(A_{S U}\right)_{i j} x_{j} \geq 1, \forall j=1,2, . ., n, x_{j} \in\{0,1\}\right\}
$$

Perhatikan bahwa formulasi diatas merupakan masalah optimisasi linier integer. Dengan demikian, diperlukan penyelesaian masalah ini memerlukan suatu skema khusus untuk menangani eksistensi dari variabel biner ini. Dalam paper ini dipilih Skema Branch and Bound [6] dalam penyelesaian simulasi numerik dari masalah.

\section{Hasil dan Pembahasan}

Pada subseksi ini, Model Optimisasi Pemilihan Media Periklanan seperti yang disajikan pada formulasi (14) akan diaplikasikan dengan menyajikan suatu contoh kasus dari masalah pemilihan media periklanan, dengan menampilkan suatu masalah dengan 6 tipe audien dan 8 jenis media periklanan. Data ilustratif dapat dilihat pada Tabel berikut.

Tabel 4.1 Data ilustratif pemilihan media [1]

\begin{tabular}{|l|c|c|c|c|c|l|l|}
\hline Media (j) & \multicolumn{5}{|c|}{ Tipe Audiens } & $\begin{array}{l}\text { Biaya } \\
\text { (Ribuan }\end{array}$ \\
\cline { 2 - 7 } & $\mathrm{S}$ & $\mathrm{S}_{2}$ & $\mathrm{~S}_{3}$ & $\mathrm{~S}$ & $\mathrm{~S}$ & $\mathrm{~S}_{6}$ & \multicolumn{2}{l|}{} \\
& 1 & & & 4 & 5 & & \\
\hline Majalah & $\mathrm{x}$ & - & - & $\mathrm{x}$ & - & - & 20 \\
\hline TVmalam & - & $\mathrm{x}$ & $\mathrm{x}$ & - & - & - & 50 \\
\hline
\end{tabular}




\begin{tabular}{|l|c|c|c|c|c|c|c|}
\hline $\begin{array}{l}\text { TVprime } \\
\text { time }\end{array}$ & - & $\mathrm{x}$ & - & - & - & $\mathrm{x}$ & 60 \\
\hline $\begin{array}{l}\text { Papan } \\
\text { iklan } \\
\text { kereta }\end{array}$ & $\mathrm{x}$ & - & - & - & - & $\mathrm{x}$ & 45 \\
\hline $\begin{array}{l}\text { Papan } \\
\text { iklan bis }\end{array}$ & - & - & $\mathrm{x}$ & - & - & - & 30 \\
\hline $\begin{array}{l}\text { Koran } \\
\text { nasional }\end{array}$ & - & - & - & $\mathrm{x}$ & - & $\mathrm{x}$ & 55 \\
\hline $\begin{array}{l}\text { Koran } \\
\text { ekonomi }\end{array}$ & - & $\mathrm{x}$ & - & - & $\mathrm{x}$ & - & 60 \\
\hline $\begin{array}{l}\text { Koran } \\
\text { regional }\end{array}$ & $\mathrm{x}$ & - & - & - & $\mathrm{x}$ & - & 52 \\
\hline
\end{tabular}

Dari tabel diatas, dapat ditentukan:

1. Himpunan dari tipe audiens dinotasikan dengan $S$ dimna $S=\left\{S_{1}, S_{2}, . ., S_{n}\right\}$.

2. Himpunan dari tipe media $j$ dinotasikan dengan $U_{j}$, dimana $U=\bigcup_{j=1}^{8} U_{j}$

dimana

$$
\begin{aligned}
& U_{1}=\left\{S_{1}, S_{4}\right\}, U_{2}=\left\{S_{2}, S_{3}\right\}, U_{3}=\left\{S_{2}, S_{6}\right\}, U_{4}=\left\{S_{1}, S_{6}\right\}, \\
& U_{5}=\left\{S_{3}\right\}, U_{6}=\left\{S_{4}, S_{6}\right\}, U_{7}=\left\{S_{2}, S_{5}\right\}, U_{8}=\left\{S_{1}, S_{5}\right\} .
\end{aligned}
$$

dengan $U_{1}$ adalah majalah, $U_{2}$ adalah TV malah; $U_{3}=$ TVprime time; $U_{4}=$ Papan iklan kereta; $U_{5}=$ Papan iklan bis; $U_{6}=$ Koran nasional; $U_{7}=$ Koran ekonomi; $U_{8}=$ Koran Regional.

3. Fungsi objektif dan fungsi kendala dinyatakan dalam model formulasi (14),

$$
\begin{aligned}
& \min \sum_{j=1}^{n} c_{j} x_{j} \\
& \text { s.t } \sum_{j=1}^{n}\left(A_{S U}\right)_{i j} x_{j} \geq 1, \forall j=1,2, . ., n, \\
& x_{j} \in\{0,1\}
\end{aligned}
$$

Dimana variabel $x_{j}$ didefinisikan sebagai variabel keputusan yang bersesuaian dengan himpuan $U_{j}$. Untuk masalah diatas diperoleh 


$$
\begin{aligned}
& x=\left[x_{1}, x_{2}, \ldots, x_{8}\right] ; \\
& c=[20,50,60,45,30,55,60,52] ; \\
& A_{S U}=\left[\begin{array}{cccccccc}
1 & 0 & 0 & 1 & 0 & 0 & 0 & 1 \\
0 & 1 & 1 & 0 & 0 & 0 & 1 & 0 \\
0 & 1 & 0 & 0 & 1 & 0 & 0 & 0 \\
1 & 0 & 0 & 0 & 0 & 1 & 0 & 0 \\
0 & 0 & 0 & 0 & 0 & 0 & 1 & 1 \\
0 & 0 & 1 & 1 & 0 & 1 & 0 & 0
\end{array}\right] .
\end{aligned}
$$

\subsection{Masalah Pemilihan Media Periklanan Sebagai Masalah Linear Integer Programming}

Sebagai langkah awal, masalah diatas dipandang sebagai masalah LP biasa sehingga dapat diselesaikan dengan Metode Simplex biasa (lihat [3] dan [4]), yaitu dengan melakukan relaksasi terhadap batasan variabel. Dalam hal ini, diasumsikan variabel $x_{j}$ adalah variabel kontinyu bernilai nonnegatif.

$$
\min \left\{\sum_{j=1}^{n} c_{j} x_{j}: \sum_{j=1}^{n}\left(A_{S U}\right)_{i j} x_{j} \geq 1, \forall j=1,2, . ., n, x_{j} \geq 0\right\}
$$

Hasil perhitungan yang diperoleh dengan menggunakan LP adalah:

$$
x_{1}=\mathbf{0 . 5} ; x_{2}=\mathbf{0} ; x_{3}=\mathbf{0} ; x_{4}=\mathbf{0 . 5} ; x_{5}=\mathbf{1} ; x_{6}=\mathbf{0 . 5} ; x_{7}=\mathbf{1} ; x_{8}=\mathbf{0} ; \mathbf{z}=\mathbf{1 5 0} \text {. }
$$

Perhatikan bahwa hasil yang diperoleh belum realistis, karena masih ada nilai yang belum bernilai integer, maka perhitungan selanjutnya dilakukan dengan memandang masalah sebagai integer programming. Dalam hal ini, digunakan Skema Branch and Bound (lihat [6]) sederhana untuk memperoleh solusi integer terdekat, sehingga diperoleh solusii optimal berikut:

$$
x_{1}=1 ; x_{2}=0 ; x_{3}=0 ; x_{4}=1 ; x_{5}=1 ; x_{6}=0 ; x_{7}=1 ; x_{8}=\mathbf{0} \text { dan } \mathbf{z}=155 \text {. }
$$

Dari hasil perhitungan ini, dapat disimpulkan bahwa bahwa media periklanan yang dipilih adalah majalah, papan iklan kereta, papan iklan bis, dan koran ekonomi. Dapat dilihat pula bahwa type 1 dijangkau dua kali oleh majalah dan papan iklan kereta, type 2 dijangkau oleh koran ekonomi, type 3 dijangkau oleh papan iklan bis, type 4 dijangkau oleh majalah, type 5 dijangkau oleh koran ekonomi dan type 6 dijangkau oleh papan iklan kereta. Total biaya yang dikeluarkan adalah Rp. 155.000,-.

\subsection{Penambahan Kondisi Logis}

Pada subseksi ini, aplikasi dari teori Conditional Constraints disajikan.

Kasus 1: Dalam masalah ini diasumsikan bahwa perusahaan ingin menggabungkan beberapa TV dalam semua kasus, dikarenakan pada solusi integer sebelumnya TV komersial belum dipilih. Sedangkan TV merupakan salah satu media yang sangat efektif dalam media periklanan. Dapat dimodelkan kondisi sebagai berikut: 


$$
x_{2}+x_{3} \geq \mathbf{1}
$$

Kendala ini mengecualikan situasi dimana keduanya bernilai nol. Artinya harus dipilih keduanya atau salah satunya. Dengan memasukkan kondisi tersebut ke dalam batasan masalah awal, hasil yang diperoleh adalah

$$
x_{1}=\mathbf{0} ; x_{2}=1 ; x_{3}=\mathbf{0} ; x_{4}=\mathbf{0} ; x_{5}=\mathbf{0} ; x_{6}=1 ; x_{7}=\mathbf{0} ; x_{8}=\mathbf{1} ; \mathbf{z}=\mathbf{1 5 7 , 5 0 0 . 0 0} .
$$

Artinya bahwa media periklanan yang dipilih adalah TVmalam, koran nasional dan koran regional. TVmalam menjangkau type 2 dan type 3, koran nasional menjangkaur type 4 dan type 6 , dan koran regional menjangkau type 1 dan type 5. Total biaya meningkat menjadi Rp. 157.500,-.

Kasus 2: Asumsikan bahwa jika sebuah papan iklan dipilih maka TV juga harus dipilih. Kedua media tersebut saling menguatkan satu sama lain. Masalah ini dapat dideskripsikan sebagai berikut:

Jika setidaknya satu kemungkinan papan iklan dipilih, maka setidaknya satu kemungkinan TV harus dipilih dan ika setidaknya satu kemungkinan TV dipilih, maka setidaknya satu kemungkinan papan iklan harus dipilih.

Kondisi di atas dapat dimodelkan sebagai berikut:

$$
\begin{aligned}
& x_{2}+x_{3} \geq x_{4} \\
& x_{2}+x_{3} \geq x_{5} \\
& x_{4}+x_{5} \geq x_{2} \\
& x_{4}+x_{5} \geq x_{3}
\end{aligned}
$$

Kondisi di atas menjadi kendala logis dan dimasukkan ke dalam masalah sebelumnya. Solusi optimal yang diperoleh adalah:

$$
x_{1}=1 ; x_{2}=\mathbf{0} ; x_{3}=1 ; x_{4}=\mathbf{0} ; x_{5}=1 ; x_{6}=\mathbf{0} ; x_{7}=\mathbf{0} ; x_{8}=\mathbf{1} \text { dan } \mathbf{z}=\mathbf{1 6 2 . 5} \text {. }
$$

Artinya bahwa media periklanan yang dipilih adalah majalah, TVprime time, papan iklan bis, dan koran regional. Type 1 dijangkau dua kali oleh majalah dan koran regional, type 2 dijangkau oleh TVprimetime, type 3 dijangkau oleh papan iklan bis, type 4 dijangkau oleh majalah, type 5 dijangkau oleh koran regional dan type 6 dijangkau oleh TVprime time. Total biaya adalah Rp. 162.500,-

Kasus 3: Diasumsikan bahwa jika TVprime time dipilih, maka tidak ada satu pun papan iklan yang dipilih. Maka kita dapat menggambarkan masalah di atas sebagai berikut:

Jika TVprime time dipilih maka tidak ada satu pun papan iklan dipilih.

Kondisi ini dapat dimodelkan:

$$
x_{4}+x_{5} \geq 2\left(1-x_{2}\right)
$$

Masukkan kondisi di atas menjadi kendala logis ke dalam masalah sebelumnya. Solusi optimal yang diperoleh adalah 


$$
x_{1}=\mathbf{1} ; x_{2}=\mathbf{1} ; x_{3}=\mathbf{0} ; x_{4}=\mathbf{1} ; x_{5}=\mathbf{0} ; x_{6}=\mathbf{0} ; x_{7}=\mathbf{0} ; x_{8}=\mathbf{1} \text { dan } \mathbf{z}=\mathbf{1 6 7 . 5} .
$$

Artinya bahwa media periklanan yang dipilih adalah majalah, TVmalam, papan iklan kereta, dan koran regional. Type 1 dijangkau tiga kali oleh majalah, papan iklan kereta dan koran regional, type 2 dijangkau oleh TVmalam, type 3 dijangkau oleh TVmalam, type 4 dijangkau oleh majalah, type 5 dijangkau oleh koran regional dan type 6 dijangkau oleh papan iklan kereta. Total biaya adalah Rp. 167.500,-.

Kasus 4: Asumsikan bahwa jika koran ekonomi dipilih pada model pemilihan media, maka harus TVmalam dan majalah juga harus dipilih. Masalah di atas dapat digambarkan sebagai berikut:

Jika TVmalam dan majalah harus dipilih maka koran ekonomi harus dipilih.

Kondisi ini dapat dimodelkan:

$$
x_{7} \geq x_{2}+x_{1}-1
$$

Masukkan kondisi di atas menjadi kendala logis ke dalam masalah sebelumnya. Solusi optimal yang diperoleh adalah:

$$
x_{1}=\mathbf{1} ; x_{2}=\mathbf{1} ; x_{3}=\mathbf{0} ; x_{4}=\mathbf{1} ; x_{5}=\mathbf{0} ; x_{6}=\mathbf{0} ; x_{7}=\mathbf{1} ; x_{8}=\mathbf{0} \text { dan } \mathbf{z}=\mathbf{1 7 5} \text {. }
$$

Artinya bahwa media periklanan yang dipilih adalah majalah, TVmalam, papan iklan kereta, dan koran ekonomi. Type 1 dijangkau dua kali oleh majalah dan papan iklan kereta, type 2 dijangkau dua kali oleh TVmalam dan koran ekonomi, type 3 dijangkau oleh TVmalam, type 4 dijangkau oleh majalah, type 5 dijangkau oleh koran ekonomi dan type 6 dijangkau oleh papan iklan kereta. Total biaya adalah Rp. 175.000,-. Dapat dilihat type 1 dan type 2 terjangkau 2 kali.

\section{Kasus 5:}

Penambahan kondisi logis terakhir melibatkan type audiens. Pada solusi yang terakhir didapat type audiens yang terjangkau dua kali adalah dua type audiens. Akan dilihat type audiens yang terjangkau lebih dari satu kali. Secara khusus tetapkan bahwa harus ada tiga type audiens yang terjangkau lebih dari satu kali, dapat dimodelkan sebagai berikut:

Setidaknya tiga type audiens terjangkau lebih dari satu kali. Formulasi kondisi di atas adalah dengan menambahkan variabel $y_{t}$ yang diperkenalkan untuk setiap type audiens $t$. Variabel ini bernilai biner 0 dan 1 . Nilai 1 hanya dinyatakan untuk type audiens yang terjangkau lebih dari satu kali. Karena kita memodelkan tiga type yang harus terjangkau lebih dari satu kali, maka jumlah semua variabel harus lebih besar atau sama dengan tiga. Sehingga model dapat diperluas dengan menambahkan variabel dan kendala sebagai berikut: 


$$
\begin{aligned}
& 2 y_{t} \leq \sum_{m} N_{t m} x_{m}, \forall t ; \\
& \sum_{t} y_{t} \geq 3 ; \\
& y_{t} \in\{0,1\} .
\end{aligned}
$$

Masukkan kondisi di atas menjadi kendala logis ke dalam masalah sebelumnya. Solusi optimal yang diperoleh adalah:

$$
\begin{aligned}
& x_{1}=\mathbf{1} ; x_{2}=\mathbf{1} ; x_{3}=\mathbf{0} ; x_{4}=\mathbf{1} ; x_{5}=\mathbf{1} ; x_{6}=\mathbf{0} ; x_{7}=\mathbf{1} ; x_{8}=\mathbf{0}, \\
& y_{1}=\mathbf{1} ; y_{2}=\mathbf{1} ; y_{3}=\mathbf{1} ; y_{4}=\mathbf{0} ; y_{5}=\mathbf{0} ; y_{6}=\mathbf{0} ; y_{7}=\mathbf{0} ; y_{8}=\mathbf{0}, \boldsymbol{d a n} z=\mathbf{2 0 5} .
\end{aligned}
$$

Artinya semua media dipilih untuk media periklanan, kecuali TVPrime time, koran nasional dan koran regional. Dan ada 3 type audiens yang terjangkau lebih dari satu kali, yaitu type 1 , type 2 , dan type 3 . Type 1 dijangkau oleh majalah dan papan iklan kereta, type 2 dijangkau oleh TVmalam dan koran ekonomi, type 3 dijangkau oleh TVmalam dan papan iklan bis. Sedangkan type 4, type 5 dan type 6 hanya dijangkau 1 kali. Type 4 dijangkau oleh majalah, type 5 dijangkau oleh koran ekonomi, type 6 dijangkau oleh papan iklan kereta. Dan total biaya adalah Rp. 205.000,-.

Tabel 2. Skenario alternative untuk pemilihan media periklanan untuk setiap Kondisi Logis

\begin{tabular}{|c|c|c|c|c|c|c|c|}
\hline \multirow{2}{*}{$\begin{array}{c}\text { Variabel } \\
\text { Jenis Media }\end{array}$} & \multirow{5}{*}{ LP } & \multirow{2}{*}{ IP } & \multicolumn{5}{c|}{ IP + Conditional Constraints } \\
\cline { 2 - 8 } & & & $\begin{array}{c}\text { Kasus } \\
1\end{array}$ & Kasus 2 & Kasus 3 & Kasus 4 & Kasus 5 \\
\hline$x_{1}$ & 0,5 & 1 & 0 & 1 & 1 & 1 & 1 \\
\hline$x_{2}$ & 0 & 0 & 1 & 0 & 1 & 1 & 1 \\
\hline$x_{3}$ & 0 & 0 & 0 & 1 & 0 & 0 & 0 \\
\hline$x_{4}$ & 0,5 & 1 & 0 & 0 & 1 & 1 & 1 \\
\hline$x_{5}$ & 1 & 1 & 0 & 1 & 0 & 0 & 1 \\
\hline$x_{6}$ & 0,5 & 0 & 1 & 0 & 0 & 0 & 0 \\
\hline$x_{7}$ & 1 & 1 & 0 & 0 & 0 & 1 & 1 \\
\hline$x_{8}$ & 0 & 0 & 1 & 1 & 1 & 0 & 0 \\
\hline $\begin{array}{c}\text { NilaiFungsi } \\
\text { Objektif(dal } \\
\text { am ribuan } \\
\text { rupiah) }\end{array}$ & $\mathbf{1 5 0}$ & $\mathbf{1 5 5}$ & $\mathbf{1 5 7 . 5}$ & $\mathbf{1 6 2 . 5}$ & $\mathbf{1 6 7 . 5}$ & $\mathbf{1 7 5}$ & $\mathbf{2 0 5}$ \\
\hline
\end{tabular}


Perhitungan yang dilakukan pada penambahan kondisi logis adalah dengan menggunakan konsep Set Covering dan dilakukan dengan bantuan Software Aplikasi Maple 10. Dari penambahan kondisi logis di atas, perusahaan dapat memilih beberapa alternatif pemilihan media. Pada kondisi awal, biaya yang dikeluarkan adalah Rp. 155,- dan pada kondisi terakhir biaya yang dikeluarkan adalah Rp. 205.000,-. Dapat dilihat bahwa biaya yang dikeluarkan pada setiap kondisi semakin meningkat, tetapi type audiens yang dijangkau oleh media semakin luas. Pada kondsi awal, terlihat walaupun media sudah menjangkau semua target, tetapi ada media periklanan yang cukup efektif belum dipilih. Pada kondisi terakhir, terlihat walaupun biaya yang dikeluarkan cukup besar, tetapi setidaknya ada 3 type audiens yang sudah dijangkau lebih dari satu kali oleh media yang dipilih. Pada Tabel 2, dapat dilihat ringkasan dari hasil perhitungan untuk setiap kasus.

\section{Simpulan Dan Saran}

Masalah Pemilihan Media dapat dimodelkan dengan konsep Set Covering, dimana formulasinya merupakan model integer programming. Salah satu strategi dalam pemrograman linier integer yang digunakan dalam masalah ini adalah penambahan beberapa kondisi logis yang memberikan skenario alternatif untuk strategi pemilihan media, sebagaimana dapat dilihat pada hasil perhitungan, penambahan kondisi logis ini memberikan hasil perhitungan optimal yang lebih logis, dimana fakta yang diperoleh ada meski biaya meningkat namun tipe audiensi yang dijangkau oleh media semakin luas dan media periklanan yang efektif telah terpilih. Sebagai arahan pengembangan kajian, disarankan untuk dapat mengimplementasikannya dalam masalah real di lapangan.

\section{Daftar Pustaka}

1. Bisschop, J. 1999. AIMMS Optmization Modeling. Paragon decision technology BV. Harleem The Netherland.

2. Calantone, R.J and Todorovic, U d B., 1981. The Maturation of the Science of Media Selection. Journal of the Academy of Marketing Science., Vol. 9, No. 4, 490-524.

3. Hillier, F. S. and Lieberman, G. J. 1991. Introduction to Mathematical Programming. United States of America: Mac Graw-Hill International Editions.

4. Rao, S. 1984. Optimization: Theory and application. Willey Eastern Limited.

5. Schrijver, A. 2003. Combinatorial Optimzation. Germany: SpringVoslag.

6. Wolsey, Laurence A. 1998, Integer Programming, United States of America: John Wiley \& Sons, Inc. 